\title{
ETHICS AND THE GOVERNANCE OF THE INTERNET: RECOMMENDATIONS OF IFIP - SIG9.2.2
}

\author{
Jacques Berleur \\ IFIP-SIG 9.2.2 Chair \\ Facultés Universitaires Notre-Dame de la Paix, \\ Namur, Belgium
}

\begin{abstract}
There is an increasingly dynamic debate about the ethics of regulating the Internet: the issues are provocative and controversial. Certain profoundly challenging ethical issues surround the question of Internet governance. They include: equity of access; justice and social exclusion; the dignity of users; and respect for the interests and rights of users. As a result of deliberations that took place at the HCC5 conference, IFIP's special interest group on a Framework for Ethics recommends to its, and to IFIP's, members to become more active in the debate about the ethics of governing the Internet. Faithful to the group's creed of creating spaces for discussion locally and internationally, this paper poses a series of pertinent, pressing questions about the ethics of Internet governance that it believes should form a more active part of the public debate.
\end{abstract}

\section{INTRODUCTION}

As a result of HCC 5, IFIP SIG 9.2.2 wishes to make a number of recommendations about ethics and the governance of the Internet. It is the group's intention to promote discussion among the IFIP national societies and, more widely, among the professional and scientific computing community.

The following text is the result of what was called during HCC 5 a 'Series of Rolling Workshops and Round Table'. It has been elaborated after the Conference as a result of the discussion held there. The process of running the workshops and the round table is explained in a separate paper by Duquenoy and Whitehouse. These texts, along with other papers, have been published as a monograph by the IFIP Press (Berleur, Duquenoy and Whitehouse 1999) ${ }^{1}$.

This introductory paper is intended as an overview of the current debates surrounding use of the Internet and regulation of the communications possibilities that the net offers. The paper lists a number of topics that have an ethical content, and highlights some issues that are coming to the fore in the debate. Finally, it makes a series of three recommendations to the member societies of the International Federation for Information Processing 
(IFIP), urging those members to take these suggestions on board. It also encourages IFIP member societies to answer ten very specific questions about the work that they may be doing in the area of ethics and the Internet.

\section{2. 'INTERNET GOVERNANCE'?}

Lists of websites may quickly leave the impression that the words 'Internet governance' are linked today to the environment of domain name administration. Search engines readily refer to the homepages of IANA (Internet Assigned Names Authority), its substitute ICANN (The Internet Corporation for Assigned Names and Numbers), and the new IANA Corporation (Internet Addressing and Naming Authority) ${ }^{2}$

But when the CPSR (Computer Professionals for Social Responsibility) launched its 'One Planet, One Net: CPSR Campaign on Internet Governance' in December 1997, it was "undertaking a broader examination of the issues in standards development, content development and control, and access to the Internet." 'The Principles for the Internet Era' cover a wider area than simply domain names and addresses. They are principles intended "to counter the political, economic, social, and technical forces that (...) threaten the promise of open communication on the Internet." 3

The European Commission's Information Society Project Office (ISPO) presents on its homepage the project of Internet Governance, and seems to come back to a narrower understanding. It mentions:

- management of Internet Names and Addresses;

- international policy issues related to Internet Governance;

- Internet Governance reply of the EC and its Member States to the US Green Paper; and

- $\quad$ domain names. 4

We adopt a more open position than the European Commission, considering the currently predominant DNS (Domain Naming System) question as just one example of a larger debate among different interested parties such as technical organisations, businesses or groups of businesses, higher education institutions, and governments. The current debate between the USA and Europe also points to controversies over control of the Internet (EU 1998). Everybody knows the issues at stake regarding Internet self-regulation, or in other words, the place of official governments and national or international authorities in ruling cyberspace, democracy on the Internet, its multiculturality, the place of the developing countries in the universal service, etc. 5 We think that all these kinds of questions fall under the scope of 'Internet governance'.

As will appear in the report on the rolling workshops and the round table held during IFIP TC9 HCC 5 Conference (Duquenoy and Whitehouse, this volume), our approach has been inspired by a paper of Joel Reidenberg 
(1996) and suggests a three-way Internet governance: technical, selfregulating and legal.

\section{DO WE NEED INTERNET GOVERNANCE?}

The Internet has grown for a long time without too much regulation. Defining protocols and standards had been for a long time the most developed regulatory activity. But as soon as business took its place, the requirements changed. People present at the closing session of the IFIP WCC'94 in Hamburg surely remember those who spoke about creating a "second Internet" dedicated to business, if safer measures were not to be taken. Standards and routing administration, encryption, digital signature, Internet service providers licensing, property rights, tariffs, computer crime, etc. were questions raised as soon as commerce came to the forefront. 6

In particular, the management of Internet names and addresses is considered as critical to the stability and inter-operability of the Internet. The allocation of domain names is of utmost significance for the organisations concerned, users and trademark owners.

The debate is now lively because the key issue is, What kind of regulation? Rules by governments or self-regulation by business and users? Because of its history, some highly sensitive features surround the concept of governance of the Internet. The Blue Ribbon Campaign and similar anticensorship manifestations hark back to the origins, when the Internet was mainly a tool for research and education, i.e., operating according to the principle of 'academic freedom.'

Is more regulation needed? Those who advocate more regulation feel that the Internet today is chaotic and unmanaged and also weakly self-regulated. Examples were given during the HCC 5 session devoted to self-regulation. New associations created in the meantime do not alter these views. Most of the 'codes' are created "to curb government regulation of the Internet", and it is sometimes even proclaimed as such. Here are some recent private initiatives.

- The Global Business Dialogue on Electronic Commerce: an initiative of top executives "to prevent conflicting governmental regulations from obstructing business in cyberspace." (Harmon 1999)

- the Electronic Commerce Platform Netherlands (ECP-NL): a platform coordinating initiatives in electronic commerce that has drafted a code of conduct, currently submitted for comments to 'all interested parties,' and proposed for discussion at both the OECD level and at a conference to be held in the Netherlands in the presence of US Commerce Secretary William M. Daley (ECP-NL 1999).

- Electronic Commerce Europe, which considers that codes of conduct are the structuring approach to Electronic Commerce. 7 
The ICRA (Internet Content Rating Association) ${ }^{8}$ : the Bertelsmann Foundation is organising (Munich, September 9-11, 1999) a 'summit' (sic) on 'Self-regulation of the Internet Content'. "The Internet Content Summit is the first milestone in the implementation of an international self-regulatory system to deal with the protection of minors online. The conference is organised and funded by the Bertelsmann Foundation in cooperation with INCORE (Internet Content Rating for Europe)."

One may wonder if such declarations or codes of conduct are not purely instrumental, i.e., aimed at making e-commerce or any use of the Internet or ICT systems more acceptable to the public. Undoubtedly, commerce is and always has been - the big affair of mankind. It mobilises all the devices of creativity, including the newest technology. The sometimes hidden intention is to create a free-trade global market without customs, tax systems, and rules from the State (Cassen 1999). The question is to legitimate the operation: rhetoric and metaphors may help!

About the codes - let us repeat - where is the power of sanction? (see, for instance, Berleur and d'Udekem-Gevers $1996 \mathrm{pp} .7 \mathrm{ff}$ ) Are there any enforcement means? People know how sensitive these questions are. The 'ICRA Summit' has prepared a long document about this specific question of 'law enforcement' (Sieber 1999). But as far as we can see, associations where every individual member has to commit him/herself to abide by the code seem very rare!

In a way, SIG 9.2.2 regards the opposition between private and public regulation as something to be overcome, and recommends a deeper cooperation of both sectors in the domain of governance. Controversial questions such as the relationship between self-regulation and the law must be confronted. The actual credo of a 'socio-liberal third way' could lead to 'disappropriation from the State' (Petrella 1999). Others speak about a 'Governance debacle,' buried by politics (Mueller 1998). Some suggest a distinction between 'governance' and 'institutional framework,' and promote the latter (Mueller 1998). Self-regulation with conditions, or embedded in an appropriate legal framework, could be satisfactory. The pending dialogue between the USA and Europe about the transfer of personal data to third countries and the interpretation of articles 25 and 26 of the European Directive on the protection of individuals with regard to the processing of personal data will be a very interesting case study on 'selfregulation and/or the law' when it is resolved. The Directive mentions the necessity of examining the 'appropriate level of protection' of the parties, whereas the USA speaks about self-defined 'safe harbour principles.' 9 


\section{DO WE NEED INTERNET ETHICAL GOVERNANCE?}

If we need Internet governance, the question may be raised: "Do we need ethical governance?" And therefore also: "What does it mean?"

There is no need to dwell on it, since the IFIP Ethics Handbook has already elaborated this issue. Jan Holvast reminds us that Julie Cameron et al. state it very simply: "We need IT ethics because:

- $\quad$ IT is a powerful and constantly evolving tool,

- IT permeates all aspects of our lives,

- IT dependency creates vulnerability on a large scale,

- $\quad$ IT evolution and usage outstrips the formulation and implementation of policy and legal instruments." (Cameron et al 1992, quoted in Holvast 1996 47)

We ourselves have welcomed 'a revival of ethics' stressing the reappropriation of our daily life in the field of ethics, a kind of 'life-world ethics' ('le monde-vécu'), in the sense of Jürgen Habermas (Berleur and d'Udekem-Gevers 1996).

There has been a relatively easy consensus that ethics is necessary on the net when speaking about protection of minors and human dignity. The 'Action plan on promoting safer use of the Internet' is part of a coherent set of policies at the European Union level to deal with illegal and harmful content on the Internet. 10 Other international organisations such as UNESCO have also developed actions to meet this general preoccupation. But this is probably the emerging part of the iceberg.

There are also other topics that could similarly be considered as urgent ethical issues which require our attention and determine our priorities. However, this may depend upon different factors such as the culture, the place where we are living and acting, the practices at work, the motivation of people, the interests at stake, etc. SIG 9.2.2 proposal is a first exercise whose result we present here. We have classified the different topics into two categories, the first one into two sub-categories. So, the first subcategory deals with issues related to the protection of the individual (citizen and consumer). The second, with more collective issues or with the organisation of society. The last category is dedicated to topics which we feel have a more ethical content: this is why we have not only listed them, but have also given a short explanation.

We must finally add that, in our opinion, the distinction between ethical and social issues is not always quite clear today; one cultural environment may call ethics what is considered 'social informatics' in another. ${ }^{11}$ There is at least one trap we should not fall into: the distinction between ethical and social must not be considered as parallel to that between individual and 
collective. We leave that distinction between ethical and social issues open, and refer to the current literature.

\section{SIG 9.2.2 PROPOSAL OF TOPICS TO BE CONSIDERED}

We propose ongoing discussions within the IFIP Members Societies about the subjects that follow. SIG 9.2.2 also has various recommendations to make, and these then follow also.

\subsection{Topics already under discussion}

Protection of the individual (citizen and consumer)

- Questions related to risk, security, reliability, vulnerability, liability, ... (for instance in e-commerce)

- Privacy, identification, authentication (consumer), confidentiality, encryption, key escrow, trusted third party, ...

- $\quad$ Protection of competition / avoiding monopolistic practices

- Intellectual property rights, copyrights, rights on software, ...

- Computer crime / misuse

- Advertisements on the Internet: providing the customer with legal, decent, honest and truthful (adequate, accurate, ...) information.

Other questions (collective organisation of society)

- Infrastructure ownership / monopoly (see for instance the Microsoft trial ${ }^{12}$ )

- Technological dreams, utopias, computer metaphors ... and all questions linked to awareness and education

- Impact on work and organisations

- Democracy/ organisation of the civil society in accordance with the 'common good'; role of governments, political aspects, public policies, telecommunication policies, democracy, public security and order, ...

- Self-regulation.

\subsection{Topics with a more ethical content}

- Equity in the right of access ('universal service')

The importance of making information universally accessible and affordable has been stressed since the first declaration on the US National Information Infrastructure. Access to information is crucial for education, public health, ...; its accessibility to all will be a sign of democracy. The current situation cannot be considered as equitable. 
- Questions linked to the respect of the dignity of the person (protection of minors and human dignity; illegal and harmful content on the Internet, paedophilia, racial hate, denial of crimes against humanity, incitement to murder, to drug trafficking, to riot, ...)

Many national and international organisations are preoccupied by the deleterious influence that the Internet could have in such matters. The time has come to confront the different ethics and approaches to these issues and to harmonise the practices, and combat such scourges.

- Justice and social exclusion (mainly North-South, but also work distribution, ...)

Social exclusion is unfortunately a concept which is still fully relevant when speaking about the Information Highways: there, we observe discrimination and exclusion of the elderly, gender imbalance, ... What does it mean to have at one's disposal all the means for efficient work when this is accompanied by a 10 to $12 \%$ unemployment rate (or even more in certain regions of the world) or with precarious jobs, and what does an information society mean where participation in its construction is kept in the hands of a few? Most probably large minorities in the Northern countries are in danger to be excluded from the information society. But overall everybody has also to remember - as President Thabo Mbeki argued in his keynote address to a G-7 Information Society Conference - 'There are more telephone lines in Manhattan than in all of sub-Saharan Africa" and "half of humanity has never made a telephone call."13

- Respect for the interests and the rights of the persons

The Universal Declaration of Human Rights includes rights which can have an application in the field of ICT: privacy (art. 12), freedom of thought (art. 18), free speech, freedom to seek, receive and impart information and ideas (art. 19), ... This makes sense when we know that there are still 45 countries where access to the Internet is more or less strictly controlled. This may also be called also 'censorship' (see below). Today's research programs are also trying to develop concepts of cultural, economic, and social rights. ${ }^{14}$ There are also rights and interests of persons in commercial exchange, in daily life, etc. which may be affected by communications technology.

\section{- $\quad$ Free speech / censorship}

On the Internet, how to find a relevant balance between free speech and censorship (sensu lato, i.e., any kind of control)? What is the relationship between censorship and controlling the access to the Internet? Free speech and the First Amendment are arguments which are culturally located 15 , and must be examined in other contexts. The freedom of the press is a possible 
approach. One cannot avoid confronting the freedom of speech with the concept of responsibility.

- Quality of life

The 'whole person' Does technology lead to an imbalance in mind, body, spirit? Quality is a subjective term, but refers to standards. Helpful questions for discussion might be: "What standard of life do we expect, and to what extent (if any) does ICT affect those standards?" and "In what ways might ICT enhance or diminish our self-worth?"

- $\quad$ Right to information ('transparency')

The role of information in the relationship between the citizen and the administration as well as in an effective market requires that clear and sufficient information be given to the citizen or to the consumer. It implies, on the one side, easy access to government records. It also implies also, on the other - in e-commerce for instance - relevant promotional material, clear prices, terms and conditions brought to the attention of the customer, definition of complaints procedure, ... (See also above: 'advertisement on the Internet')

- $\quad$ Personal qualities (honesty, competence, ...)

All professional codes of conduct emphasise the personal qualities conscientiousness, honesty and positive attitude, competence and efficiency - of the individuals involved in that occupation or profession (Berleur and d'Udekem-Gevers 1996 pp.28-31).

- $\quad$ Non-abuse of power (appropriate use)

While power generally involves the use of force (particularly physical force); authority may be used to influence others through charisma; heritage; or particular attributes or skills (Max Weber 1947). In relation to the Internet, many different actors have technical influence over the way in which individuals communicate. The appropriate behaviour of authorities can be explored at several levels: the roles of the various international and federal authorities, including the police and security forces; Internet service providers (ISPs); computer service providers in educational establishments and in commercial organisations; and the activities of Internet users themselves. Debate is to be encouraged about the appropriate activities of both individuals and services, and how all these parties should ideally act (lawfully, democratically, and in an egalitarian manner).

- $\quad$ Respect for cultural differences

In the face of US cultural supremacy in many domains (for instance in values conveyed by current filtering services), European, Asian, Latin 
American, and African countries must be encouraged to make respect for cultural differences a major concern.

- Freedom of choice in the use or non-use of the Internet

Neo-Luddism? ${ }^{16}$ Could we exist without communications media that employ the highest of high technology? Most of us would certainly agree that there is much to criticise in many manifestations of modern technology. The sorting out of what works from what doesn't - and why, and if it is needed - is the kind of public dialogue about technology that we need. Technology is thought, action, information, invention: it exists for human beings.

- Grounding 'virtual' life in the physical realm

Many people are concerned that the increasing importance of 'virtual life' will have serious psychological and social implications. Proposals have been made to encourage the use of computing to support rather than supplant real life. For example, 'community nets' are geographically based networks that help enhance real participation within a specific locality (e.g. neighbourhood, village).

\section{RECOMMENDATIONS}

1. SIG 9.2.2 recommends to IFIP members, and mainly its national or regional Societies, to represent an ethical approach when involved at the national or regional level on Internet governance policies, where key ethical issues will be defined by the specific concerns of particular nations. Some of the issues that may be of concern are those set out and classified above under the title 'Topics with a more ethical content'. SIG 9.2.2 offers its services to act as a rapporteur, and to share with other IFIP members what has been done by IFIP Members Societies and others, and what is still to be done (see the list of 'Questions Raised to the IFIP Members' below).

2. SIG 9.2.2 endorses the recommendations proposed during the HCC 5 Round Table. Let us already mention some of them here.

Let IFIP:

- $\quad$ act to mitigate unequal access to the Internet;

- $\quad$ use the Internet to develop a cross-cultural approach to the search for peace on earth;

- focus on children and families and their need to access the Internet to further their learning experiences. Promote netmaking, rather than networking, with kids;

- organise an active debate with North America on some more controversial questions relating to the ethics of the Internet;

- develop a channel or open forum for the expression of an Asian/Confucian ethics of computing. 
3. SIG 9.2.2 highly recommends that IFIP members (individuals, full member Societies, associates, affiliates, corresponding, ...) be present in the different constituencies where ICT (Information and Communication Technology) uses are discussed and where ethical principles would have to be considered in order to promote these principles.

As examples of constituencies, SIG 9.2.2 suggests among others UNESCO and its World Commission on the Ethics of Scientific Knowledge and Technology 17, the European Commission and especially its Information Society Project Office, the different associations where issues are discussed (see the above mentioned Internet Content Rating Association, the Electronic Commerce Platform Netherlands, the Global Business Dialogue, ...; but also associations such as the Internet Society, the Electronic Frontier Foundation, the Computer Professional for Social Responsibilities, Privacy International, etc.)

As far as ethical principles are concerned, SIG 9.2.2 names the issues at stake, among others, in the above mentioned Action Plan of the European Commission on promoting safer use of the Internet or in Electronic commerce $^{18}$, or in property rights (e.g. plagiarism would be a specific ethical issue), etc. Other issues may be found in our list of topics. The CPSR 'One Net principles' could be also considered as deontological principles.

\section{QUESTIONS RAISED TO THE IFIP MEMBERS}

Let us conclude this introductory paper by raising some questions that we would like to see examined by IFIP Member Societies. Faithful to its creed of creating spaces for discussion locally and internationally, SIG 9.2.2 will be happy to report on the answers it receives on the following questions:

1. Is there a specific ethical committee in your Society?

2. If your Society has no specific Ethics Committee, does it have a particular group in charge of handling ethical questions?

3. Do you intend to work on the recommendations of this brochure? How?

4. Has your Society already taken action on any of these recommendations?

5. On what specific topics related to ethical matters has your Society been working in the last two years? As an international body, SIG 9.2.2 would be happy to compare which are the specific ethical issues related to the governance of the Internet, as they are perceived by different cultures or in different countries.

6. Is there any written document resulting from your work? Is it available, and where? Could you put it at the disposal of SIG 9.2.2, and specify if it is public, and can be circulated?

7. In which national or regional organisations or groups is your Society present and active on ethical matters?

8. Can you describe, for the benefit of other IFIP members, some of the results of your activities? 
9. Has your Society a Code of Conduct/Ethics? What was its date of publication? Is it on your website, and could you give us the exact URL? Is it translated, and available on the Internet in English? (Enclosed is the list of IFIP Member Societies codes at our disposal, with the latest dates of publication or revision. ${ }^{19}$ )

10. Does your Society intend or feel a need to update its Code of Conduct/Ethics according to the new uses to which the new technology can be put (Internet, e-commerce, tele-medicine, etc.)? In case your Society has already completed this work, can you provide SIG 9.2.2 with the updated version?

\section{NOTES}

1 We wish to express our gratitude to the IFIP Press for having authorised this reprint.

2 See http://www.iana.org and http://www.icann.org For the discussion with the European authorities see, for instance, Internet Governance, Reply of the European Community and its Member States to the US Green Paper http://www.ispo.cec.be/eif/policy/govreply.html

3 The 1997 text of CPSR be found with other documents of the CPSR campaign at: http://www.cpsr.org/program/nii/onenet.html (The page was updated December 8, 1999) The question "Why Internet Governance?" is treated again in the Spring 1998 issue of the CPSR Newsletter.

4 http://www.ispo.cec.be

5 One may be interested in consulting the categories of the 'Quicklinks' of the European Legal Advisory Board to have an idea of the current topics in debate on 'Legal and regulatory aspects of Internet and the information society': Access to public sector information / IT in government, Competition, Computer crime, Consumer protection, Content regulation, Convergence of telecommunications, media and information technology, Copyright, trademarks and patents, Data Protection (privacy), Digital signatures, Domain names, Electronic commerce, Electronic democracy, Employment and social issues, Euro and millennium bug, Information society and Internet policy, Interception, Internet access and use, IT in education, Junk mail (Spam), Liability, jurisdiction and applicable law, Multilingual content and software, Multimedia content and tools, Protection of minors, Quality of service, Rating and filtering, Security and encryption, Self-regulation / codes of conduct, Standards, Taxation and tariffs, Universal service ('Links to news items about legal and regulatory aspects of Internet and the information society, particularly those relating to information content, and market and technology', edited by Richard Swetenham, EC, DGXIII, http://www.qlinks.net

6 A list of some twenty issues is given on the 'Issues' page of the European Electronic A list of some twenty issues is given on the 'Issues' page of the Europe
Commerce Initiative, http://www.ispo.cec.be/ecommerce/issues.htm

7 http://www.e-betobe.com/code/code.html

8 The founding companies of ICRA include AOL Europe, Bertelsmann Foundation, British Telecommunications plc (BT), Cable \& Wireless, Demon Internet (UK), EuroISPA, IBM, Internet Watch Foundation, Microsoft, Software \& Information Industry Association, and T-Online Germany.

http://www.stiftung.bertelsmann.de/internetcontent/english/frameset home.htm

9 Department of Commerce, Elements of Effective Self Regulation for the Protection of Privacy and Questions related to Online Privacy,

(http://www.ntia.doc.gov/ntiahome/privacy/6 5 98fedreg.htm) Data Protection Working Party Working Document, Transfers of personal data to third countries: Applying Articles 25 and 26 of the EU data protection directive, DGXV D/5025/98 WP12, 24 July 1998, http://europa.eu.int/comm/dg15/en/media/dataprot/wpdocs/index.htm, and 'Opinion $7 / 99$ on the Level of Data Protection provided by the 'Safe Harbor' Principles as published together with the Frequently Asked questions (FAQs) and other related 
documents on 15 and 16 November 1999 by the US Department of Commerce', European Commission, Directorate General 'Media, Information Society \& Data Protection', DG XV 5146/99 - WP 27, 3 December 1999. http://europa.eu.int/comm/dg15/en/media/dataprot/wpdocs/index.htm Parliament and of the Council of 25 January 1999 adopting a multiannual Community action plan on promoting safer use of the Internet by combating illegal and harmful content on global networks, http://www2.echo.lu/legal/en/iap/index.html

11 See f.i. H. Tavani, 'The Tavani Bibliography of Computing, Ethics, and Social Responsibility', http://www.siu.edu/departments/coba/mgmt/iswnet/isethics/biblio/. The ImpactCS (Impact Computer and Society) Project was presented as addressing "social and ethical impact of computing", http://www.seas.gwu.edu/seas/impactcs/

12 Computerwire's coverage of the Microsoft trial has been acknowledged as the most complete and insightful in the industry: http://www.computerwire.com/msoft/

13 Information Society and Development Conference, 13-15 May 1996, Midrand, South Africa, Chair's Conclusions, http://www.ispo.cec.be/isad/isadconc.html

14 Interdisciplinary Institute for Ethics and Human Rights, http://www.unifr.ch/iiedh/english/

15 Among others: The Electronic Frontier Foundation and its Blue Ribbon Campaign for Online Free Speech (http://www.eff.org/), the Global Internet Liberty Campaign (http://www.gilc.org),...

16 http://www.luddites.com/

17 http://www.unesco.org/ethics/uk/connaissances/

18 Electronic Commerce is often considered today as one of the 'killing applications' of the Information Highway. For the USA, see the official site of the Department of Commerce, United States Government Electronic Commerce Policy,

http://www.ecommerce.gov For Europe, Electronic Commerce and the European Union, http://www.ispo.cec.be/ecommerce/. But there are lots of other sites, by country, such as for France, Mission commerce électronique, http://www.finances.gouv.fr/mission commerce electronique/, without forgetting the G8 pilot project 'A Global Marketplace for the SMEs', http://www.ispo.cec.be/Ecommerce/g7init.htm

19 Some of them are available or referred to on the site of J.A.N Lee at Virginia Tech, or at the Centre for Computing and Social Responsibility, De Montfort University, Leicester, UK, http://ei.cs.vt.edu/ cs3604/lib/WorldCodes/WorldCodes.html http://www.ccsr.cms.dmu.ac.uk/resources/professionalism/codes.

\section{REFERENCES}

Berleur, J. and d'Udekem-Gevers, M. (1996) Codes of Conduct within IFIP and other Computer Societies. In Berleur, J. and Brunnstein, Kl.(eds.) Ethics of Computing: Codes, Spaces for Discussion and Law. A Handbook prepared by the IFIP Ethics Task Group. Chapman \& Hall, London.

Berleur, J., Duquenoy, P. and Whitehouse, D. (eds.) (1999) Ethics and the Governance of the Internet IFIP Press 1999, Laxenburg, 56 p. (ISBN 3-901882-03-0). It can also be downloaded, by clicking on SIG 9.2.2 'Ethics and Internet Governance', at http://www.info.fundp.ac.be/ jbl/IFIP/cadresIFIP.html

Cameron, J. et al. (1992) Ethics, Vulnerability and Information Technology. In R. M. Aiken (ed.) Information Processing 92, vol. II: Education and Society. Proceedings of the IFIP 12th World Computer Congress, Madrid, September 7-11, 1992. Elsevier Science Publishers B.V. (North-Holland), pp. 344.

Cassen, B. (1999) Adieu au rêve libertaire d'Internet. Révolution dans la Communication, Manière de voir, Le Monde Diplomatique, n 46, Juillet-Août 1999, pp. 94-95. 
ECP-NL (1999) Code of Conduct for Electronic Commerce, Draft version 3.0, November 1999, http://www.ecp.nl/ENGLISH/code.htm

EU (1998) Communication of the European Commission to the Council, International Policy Issues Related to Internet Governance, 20 February 1998, http://www.ispo.cec.be/eif/policy/governance.html

Harmon, A. (1999) Titans race to do the policing for the electronic roadway. New York Times, Jan. 18, 1999, http://www.gbd.org/library/newyorktimes.htm

Holvast, J. (1996) Discussion paper. In Berleur, J. and Brunnstein, Kl.(eds.) Ethics of Computing: Codes, Spaces for Discussion and Law. A Handbook prepared by the IFIP Ethics Task Group. Chapman \& Hall, London, p. 47.

Mueller, M. (1998) The 'governance' debacle: how the ideal of internetworking got buried by politics. INET'98 Proceedings, http://www.isoc.org/inet98/proceedings/5a/5a_1.htm

Petrella, R. (1999) La désappropriation de l'Etat. Le Monde Diplomatique, Août 1999, p. 3.

Reidenberg, J.R. (1996) Governing Networks and Rule-Making in Cyberspace, 45 Emory Law Journal, 911. Reprinted in B. Kahin and C. Nesson (eds.) (1997) Borders in Cyberspace. MIT Press.

Sieber, U. (1999) University of Würzburg, Law Enforcement, 112 p. (downloadable from the site of the Bertelsmann Stiftung)

Weber, M. (1947), The Theory of Social and Economic Organisation. Free Press.

\section{APPENDIX. IFIP Computer Societies and their Codes}

\section{IFIP National Member Societies}

- $\quad$ ACM (Association for Computing Machinery, USA): ACM Code of Ethics and Professional Conduct (1992)

- $\quad$ ACS (Australian Computer Society, Australia): ACS Code of Ethics (Received 1993)

- AICA (Associazione Italiana per l'Informatica ed il Calcolo Automatico, Italy): Codice di Condotta Professionale dei Soci Ordinari AICA (Engl. transl. 1993)

- $\quad$ BCS (British Computer Society, UK): BCS Code of Conduct: Rules of Professional Conduct (1992), BCS Code of Practice (1978)

- CIPS (Canadian Information Processing Society, Canada): CIPS Code of Ethics and Standards of Conduct (1985)

- $\quad$ CSI (Computer Society of India, India): CSI Code of Ethics (1993)

- $\quad$ CSSA (Computer Society of South Africa, South Africa): CSSA Code of Conduct (1988)

- $\quad$ CSZ (Computer Society of Zimbabwe, Zimbabwe): The CSZ Code of Ethics for Institutional Members (1992), The CSZ Code of Ethics for all Individual Members (1992), The CSZ Code of Professional Conduct for Individual Corporate Members (1992), The CSZ Code of Professional Conduct for Registered Consultants (1992), The CSZ Training Accreditation Code of Practice (1992) 
- $\quad$ FIPA (Finnish Information Processing Association): Code of Ethics (1999)

- GI (Gesellschaft für Informatik, Germany): Ethical Guidelines of the GI (1994)

- ICS (Irish Computer Society, Ireland): ICS Code of Professional Conduct (1994)

- IEEE (The Institute of Electrical and Electronics Engineers, Inc., USA): IEEE Code of Ethics (1990)

- IPSJ (Information Processing Society of Japan, Code of Ethics) (1996)

- $\quad$ NZCS (New Zealand Computer Society, Inc., New Zealand): NZCS Code of Ethics and Professional Conduct (1978)

- $\quad$ SCS (Singapore Computer Society, Singapore): SCS Professional Code of Conduct (1990)

- $\quad$ SIPIS (Swedish Information Processing Society - Dataföreningen i Sverige): Acceptable Use Policy of SUNET, and Ethical Rules for SUNET (1995)

\section{IFIP Affiliate Member Societies}

- CEPIS (Council of European Professional Informatics Societies, Europe): CEPIS Code of Professional Conduct (1992)

- $\quad$ SEARCC (South East Asia Regional Computer Confederation, South East Asia): SEARCC Code of Ethics, and SEARCC General Guidelines for the Preparation of Codes of Ethics for Members 1993) 